\title{
Bioeconomic profitability analysis of tropical gar (Atractosteus tropicus) grow-out using two commercial feeds
}

\author{
David J. Palma-Cancino ${ }^{1}$, Rafael Martinez-Garcia ${ }^{1}$, Carlos A. Álvarez-González ${ }^{1}$ \\ Ronald Jesús Contreras ${ }^{1}$, Eucario Gasca-Leyva ${ }^{2}$, Emyr Peña ${ }^{1,3}$ \& Susana Camarillo-Coop ${ }^{1}$ \\ ${ }^{1}$ Laboratorio de Acuicultura Tropical DACBIOL-UJAT, Villahermosa, Tabasco, México \\ ${ }^{2}$ CINVESTAV-IPN, Unidad Mérida, Mérida, Yucatán, México \\ ${ }^{3}$ Cátedra CONACyT \\ Corresponding author: Rafael Martinez-Garcia (biologomartinez@hotmail.com)
}

\begin{abstract}
Tropical gar (Atractosteus tropicus) aquaculture is a potential economic activity in southeast Mexico. This study analyzed the economic profitability of tropical gar grow-out using two commercial feeds (Silver Cup ${ }^{\circledR}$ and Super $^{\circledR}$ ). The last one was designed based on the digestive physiology of the species. The experiment was conducted in six concrete ponds of $4 \mathrm{~m}^{3}$ (two treatments with three replicates) for 210 days; in each experimental unit 40 juveniles were stocked with an initial average weight and a total length of $104 \pm 10$ $\mathrm{g}$ and $27.7 \pm 0.88 \mathrm{~cm}$, respectively. At the end of the grow-out, there were statistics differences $(P<0.05)$ among treatments, where fish fed with Silver Cup ${ }^{\circledR}$ obtained the highest final average weight and total length $\left(450.29 \pm 5.36 \mathrm{~g}\right.$ and $41.7 \pm 1.81 \mathrm{~cm}$, respectively), compared with fish fed Super ${ }^{\circledR}$, which obtained a final average weight and total length of $415.05 \pm 5.38 \mathrm{~g}$ and $41.4 \pm 1.57 \mathrm{~cm}$. Proximal analysis indicated a better protein content and fewer lipids in fish fed with Super ${ }^{\circledR}$. The profitability analysis showed that fish fed with Silver $\mathrm{Cup}^{\circledR}$ diet had the highest values, with a Net Present Value (NPV) = US\$55,332.63, Cost/Benefit (C/B) $=$ US\$1.5 and Internal Return Rate $($ IRR $)=48.38 \%$, while for fish fed with Super ${ }^{\circledR}$ diet was NPV = US\$50,852.28, C/B = US\$1.49 and IRR $=47.03 \%$. In conclusion, it is considered that both grow-out foods are profitable, although better nutritional value and less production cost are using Super ${ }^{\circledR}$ diet.
\end{abstract}

Keywords: Atractosteus tropicus; tropical gar; grow-out; net present value; internal return rate; bioeconomic profitability analysis

\section{INTRODUCTION}

Tropical gar Atractosteus tropicus is distributed from southeast Mexico to Central America, including countries such as Costa Rica, Guatemala, Nicaragua, Honduras and El Salvador; it represents a high consumption fishery resource in southeast Mexico (Miller et al., 2009). A. tropicus fishery represents a substantial income in rural areas as a food resource, handcraft, and aquarium product (Márquez-Couturier \& Vázquez-Navarrete, 2015).

Its high adaptability gives it great potential for captivity production (Márquez-Couturier et al., 2013). Studies about its biology and development have been essential for understanding its reproduction and captivity growth (Márquez-Couturier et al., 2006), nutritional requirements of larvae and juveniles (Frías-
Quintana et al., 2010, 2016, 2017), digestive system development and enzymatic activity (Guerrero-Zarate et al., 2013; Frías-Quintana et al., 2015), as well as grow-out (Vázquez-Navarrete \& Márquez-Couturier, 2010; Márquez-Couturier et al., 2013). Also its have been developed specific diets in order to satisfy its nutritional requirements in early stages of larvae (FríasQuintana et al., 2016), experimental grow-out of juveniles in concrete ponds and the flesh organoleptic evaluation (Jesús-Contreras, 2016) and finally a financial analysis in polyculture (González et al., 2011).

Considering those mentioned above, the absence of bioeconomic analysis in pilot production systems is one of the reasons why tropical gar aquaculture is not yet at a high commercial level (Márquez-Couturier \& Vázquez-Navarrete, 2015). For this reason, the object-

Corresponding editor: Fernando Vega-Villasante 
tive of the study was to analyze the profitability on the tropical gar grow-out at a commercial level, based on biological information obtained from the culture development reaching a commercial size, flesh proximal analysis, as well as the costs generated from the production cycle. During the culture, it was compared fish growth under conventional diet with a trout commercial feed (Silver Cup ${ }^{\circledR}$ ) (MárquezCouturier et al., 2013) and a commercial diet explicitly designed for tropical gar $\left(\right.$ Super $\left.^{\circledR}\right)$ (Jesús-Contreras, 2016). Also, it was evaluated the investment return and the benefits/cost relationship from the tropical gar grow-out and finally, several economic indicators that allowed the financial profitability analysis on this monoculture activity.

\section{MATERIALS AND METHODS}

\section{Tropical gar juveniles}

Fish were obtained from the tropical gar hatchery of Otot ibam farm, located at the $7.5 \mathrm{~km}$ ComalcalcoPotrerito Zapotal second section in Comalcalco, Tabasco, México. Produced from captivity spawnings and results from the feeding and growth system mentioned by Márquez-Couturier et al. (2013).

\section{Experimental design}

The growth-out of Atractosteus tropicus juveniles was evaluated using two commercial foods for 210 days. Feeds used were the Super ${ }^{\circledR}$ diet (specific formulated diet for tropical gar) $4.5 \mathrm{~mm}$ particle size, with $38 \%$ protein and 7\% lipids (Jesús-Contreras, 2016), and trout commercial feed, Silver $\mathrm{Cup}^{\circledR} 5.5 \mathrm{~mm}$ particle size, $42 \%$ protein and $15 \%$ lipids, conventional feed for culture (Márquez-Couturier et al., 2013). Feed Super ${ }^{\circledR}$ was formulated at the Biochemistry Laboratory UJATDACBIOL and manufactured by Consorcio Super S.A. de C.V. in Guadalajara, Jalisco, México, by a double extrusion process (Jesús-Contreras, 2016).

For the economic evaluation was designed a complete random experiment with three replicates by treatment. We used six concrete ponds $(5 \times 1 \times 1 \mathrm{~m}), 240$ fish were used with an average weight of $104 \pm 10 \mathrm{~g}$ and a length of $27.7 \pm 0.88 \mathrm{~cm}$. The first grow-out phase used 20 fish $\mathrm{m}^{-3}$ with a water volume of $2 \mathrm{~m}^{3}$, at the final phase the density was corrected for $10 \mathrm{fish} \mathrm{m}^{-3}$ and a water volume of $4 \mathrm{~m}^{3}$.

In both phases, fish were fed three times per day (9:00, 13:00 and 17:00 h). In the first phase, fish were fed with $5 \%$ of body mass and in the second phase with $3 \%$. Left overfeed was weighted in order to develop the daily consumption analysis.

\section{Growth evaluation}

For growth evaluation in weight $(\mathrm{g} \pm \mathrm{SD}$, standard deviation) and total length ( $\mathrm{cm} \pm \mathrm{SD}$ ), an initial and monthly sampling with a digital scale (Torrey) and length with a conventional ichthyometer were performed. Feeding was corrected monthly. Survival rate was calculated with a direct count of dead fish.

\section{Ponds management}

Water quality was evaluated weekly with a total water exchange and cleaning of each pond. Dissolved oxygen $\left(7.8 \pm 3.7 \mathrm{mg} \mathrm{L}^{-1}\right)$ and temperature $\left(28.2 \pm 5.9^{\circ} \mathrm{C}\right)$ was recorded with an oximeter ( $\mathrm{YSI}^{\mathrm{MR}}$ model 55), and $\mathrm{pH}$ $(7.8 \pm 0.6)$ was recorded with a $\mathrm{pH}$ meter (Denver instrument ${ }^{\circledR}$ ultraBASIC).

\section{Proximate composition analysis}

The proximate composition analysis was performed using muscle tissue of 12 fish at the beginning of the experiment with an average weight of $90 \pm 6 \mathrm{~g}$ and a total length of $26.6 \pm 0.5 \mathrm{~cm}$; the muscle was obtained from the dorsal area and then lyophilized. At the end of the experiment 15 fish (five per replicate) were sampled from Super ${ }^{\circledR}$ feed $(421 \pm 40 \mathrm{~g}$ and $41.3 \pm 1.24 \mathrm{~cm})$ and Silver Cup ${ }^{\circledR}$ feed $(454 \pm 58 \mathrm{~g}$ and $42.3 \pm 1.72 \mathrm{~cm})$. The lyophilized samples were analyzed at CIBNOR (Centro de Investigaciones Biológicas del Noroeste) in Baja California Sur, México, for protein content (Microkjeldahl \%N × 6.25), lipids (Soxtec-Avanti Tecator), humidity (weight difference at $70^{\circ} \mathrm{C} 24 \mathrm{~h}^{-1}$ ), ash

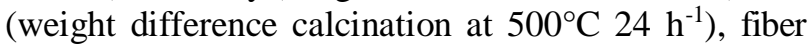
(hydrolysis acid/base method) and energy (calorimeter determination) following method described by AOAC (2000).

\section{Investment}

The necessary investment to implement an economically sustainable culture was estimated for a minimum of six tanks of $6 \mathrm{~m}$ diameter $\left(35 \mathrm{~m}^{3}\right)$, with a capacity of 3,600 fish (600 per tank) and oneproduction cycle per year (Table 2). The cost of two water pumps was estimated, a water well, a concrete pond for water storage, hydraulic material, land preparation, electric plant and set up. Finally, the land cost was estimated according to agriculture land cost (US $\$ 12.68$ per $\mathrm{m}^{2}$ ) for $500 \mathrm{~m}^{2}$.

\section{Profit and costs}

Operational costs were defined as fixed and variable costs and were estimated a cost per fish, for each diet. Fixed costs $\left(F_{C}\right)$ are the depreciation of the investment (calculated over $5 \%$ of the annual investment), for example, the cost of the fry. Variable costs were 
calculated depending on the culture time or biomass. Costs depending on culture time were: labor $\left(L_{C}\right)$, calculated using the daily minimum wage in Mexico, published in the Diario Oficial de la Federación (DOF, 2017) (US\$4.23) multiplied for worked days and number of workers (1 worker per 6 tanks is enough), energy costs $\left(E_{C}\right)$, calculated estimating the use in $\mathrm{kW}$ $\mathrm{h}^{-1}$ from the pump and illumination; veterinary costs $\left(V_{C}\right)$, material for preventing biological risks during culture, and feeding cost $\left(f_{C}\right)$, not only depends on time but also on biomass, since the daily feeding amount depends on growth $(\omega)$, therefore, the use of a function was necessary (Poot-López et al., 2014).

Total costs were estimated following:

$$
T c=F_{C}+L_{C}+E_{C}+V_{C}+\int_{0}^{\omega}\left(f_{C}(\omega)\right) d \omega
$$

Income was calculated according to the total biomass produced $(W)$, multiplied by the annual average cost per kilogram of A. tropicus ( $p$ ) in Tabasco. The value of the produced biomass (income) was calculated with the following equation (Poot-López et al., 2014):

$$
T v=p\left(W_{T}\right)
$$

With the individual cost per fish, a unitary production cost was projected over a 3,600 fish production. Further analysis was performed for the investment cost for this production.

\section{Net present value and internal rate of return}

The net present value $(N P V)$ was calculated with the annual net cash flow (NFC) considered for 10 years (investment depreciation time), using a discount rate $(i)$ of $10 \%$. The following formula was used for the NPV calculation (Barry \& Ellinger, 2010; Kay et al., 2012):

$$
N P V=-I N V+\sum_{t=1}^{T} \frac{N C F_{t}}{(1+i)^{t}}
$$

Where INV is the total costs of the initial investment, and $T$ is the total time of the project. The cost-benefit relation $(\mathrm{C} / \mathrm{B})$ was estimated with the following equation (Kay et al., 2012):

$$
\frac{C}{B}=\sum_{t=1}^{T} V t(1-r)^{-t} / \sum_{t=1}^{T} C t(1-r)^{-t}
$$

The internal rate of return (IRR) was calculated when NPV $=0$. Finally, NPV, C/B and IRR were compared for each treatment.

\section{Statistical analysis}

Individual weight, total length, proximate composition, $\mathrm{NPV}$, IRR and C/B data were analyzed in order to fulfill normality (Kolmogorov-Smirnov) and variance homoscedasticity (Levene) using a Student- $t$ analysis; survival was analyzed with chi square. All statistics were performed using Statistica v.10.0, $\alpha=0.05$.

\section{RESULTS}

\section{Growth and survival}

Growth results showed a significant difference among treatments $(P<0.05)$. The final average weight was $450.29 \pm 5.36 \mathrm{~g}$ for Silver $\mathrm{Cup}^{\circledR}$ and $415.05 \pm 5.38 \mathrm{~g}$ for Super $^{\circledR}$ (Fig. 1). Length also showed significant differences $(P<0.05)$ from the first to the fifth month. Although the two final months were not statistically different. The final average length was $41.7 \pm 1.81 \mathrm{~cm}$ for Silver $\mathrm{Cup}^{\circledR}$ and $41.4 \pm 1.57 \mathrm{~cm}$ for $\operatorname{Super}^{\circledR}$ (Fig. 2). Survival was $98.7 \%$ for both with no statistical differences.

\section{Proximal composition analysis}

Proximal analysis of tropical gar flesh tissue at the end of the experiment showed significant differences among treatments $(P<0.05)$, except for ash and fiber content (Table 1). The highest protein content was found in fish fed with Super ${ }^{\circledR}$ (75.5\%), compared with those with Silver $\operatorname{Cup}^{\circledR}$ (65.8\%). Lipids content was statistically different, Silver Cup ${ }^{\circledR}(24.7 \%)$, followed by $\operatorname{Super}^{\circledR}(16.6 \%)$. The highest significant humidity was for Super ${ }^{\circledR}(9.4 \%)$ compared to Silver Cup ${ }^{\circledR}$ $(1.2 \%)$. Highest caloric content was found in Super ${ }^{\circledR}$ $\left(5.95 \pm 0.041 \mathrm{Kcal} \mathrm{g}^{-1}\right)$.

\section{Investment costs}

In order to produce 3,600 fish, an investment of US $\$ 13,526.73$ was estimated for both cases. This investment includes the purchase of land $500 \mathrm{~m}^{2}$, equipment and material, land preparation and electrical installation, among others (Table 2).

\section{Production cost}

Fish fed with Super ${ }^{\circledR}$ consume daily on average (163.02 $\left.\mathrm{g} \mathrm{d}^{-1}\right)$, more than those fed with Silver Cup ${ }^{\circledR}(138.93 \mathrm{~g}$ $\left.\mathrm{d}^{-1}\right)$. The total feed used was $260.69 \mathrm{~kg}$ for Super ${ }^{\circledR}$ and $232.995 \mathrm{~kg}$ for Silver Cup ${ }^{\circledR}$ during all experiment. The cost of Silver Cup ${ }^{\circledR}$ was US\$1.26 per kg, compared with that of Super ${ }^{\circledR}$ US $\$ 0.92$ per kg. Each fry had a cost of US\$0.66. Thus, the total cost of the fry was US\$158.56. The total cost of electricity was US\$184.50, labor was US $\$ 888.39$, and the expenses for veterinary materials were US\$47.57 (Table 3).

\section{Benefits and income}

The total biomass produced with Super ${ }^{\circledR}$ was $48.98 \mathrm{~kg}$, compared with the biomass produced with Silver Cup ${ }^{\circledR}$ $53.13 \mathrm{~kg}$. The commercial value of the farmed tropical 


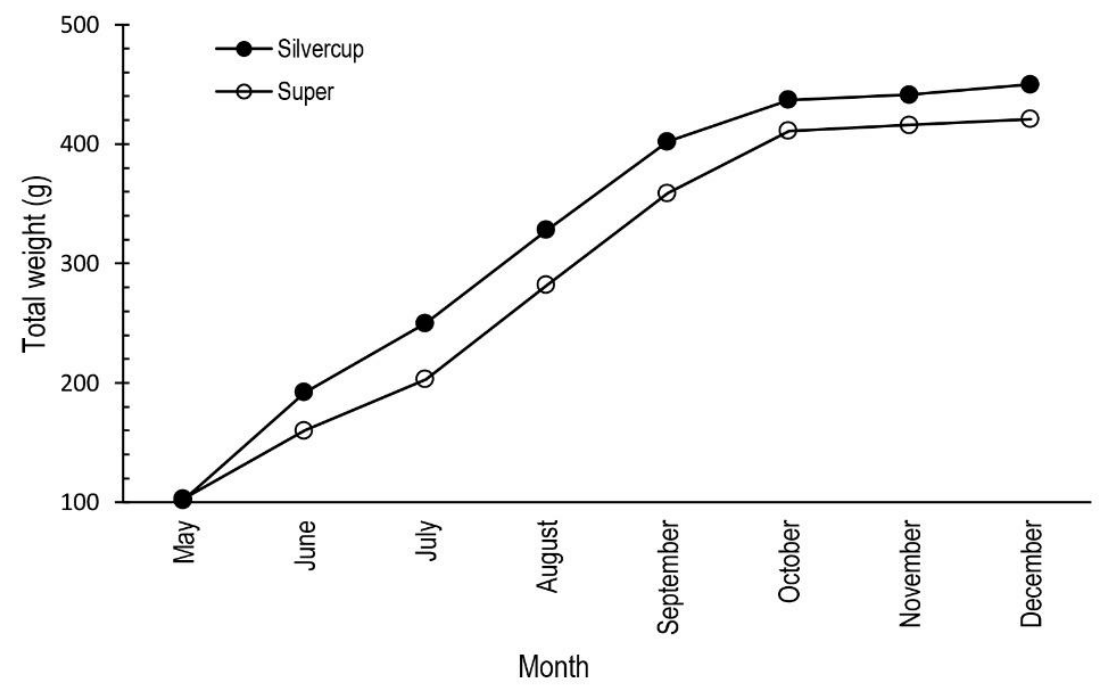

Figure 1. Mean growth weight (g) of tropical gar juveniles cultivated with commercial diets.

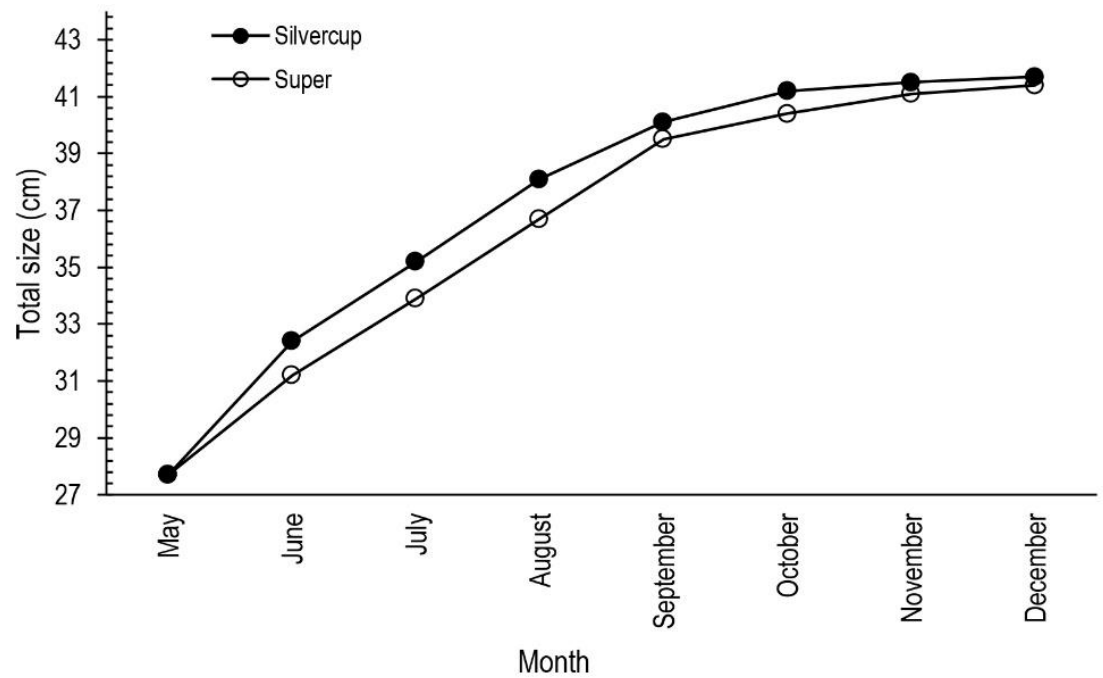

Figure 2. Mean growth size $(\mathrm{cm})$ of tropical gar juveniles cultivated with commercial diets.

gar, between 400 and $500 \mathrm{~g}$, is US $\$ 4.23$ for each organism.

The estimated biomass produced in six concrete ponds of $35 \mathrm{~m}^{3}$ with 600 fish for Super ${ }^{\circledR}$ diet was $1,479.24 \mathrm{~kg}$, with a value of US\$414.17. For the Silver $\mathrm{Cup}^{\circledR}$ diet, the biomass produced was $1,604.83 \mathrm{~kg}$, with a value of US $\$ 449.34$ (Table 4). The produced cost per fish decreased with the increment of organisms from 120 to 3,600 fish. Thus, the production cost for Super ${ }^{\circledR}$ decreased to US $\$ 1.74$. The production cost of 3,600 fish fed with Silver Cup ${ }^{\circledR}$ was US\$1.90 per fish. Therefore, the total production cost for Super ${ }^{\circledR}$ would be US\$6,253.76, while for Silver Cup ${ }^{\circledR}$ US $\$ 6,852.97$ (Table 4). The estimated income for production with Super $^{\circledR}$ would be US\$12,509.41, with a profit of
US $\$ 6,255.65$. For Silver Cup ${ }^{\circledR}$ the income would be US\$13,571.53, with a profit of US\$6,718.56.

\section{Net present value and internal rate of return}

The NPV at a minimum acceptable rate of return (MARR) of $10 \%$ during 10 years from cash flow produced from the tropical gar grow-out with Silver Cup $^{\circledR}$ was US $\$ 55,332.63$. The cost-benefit relation $(C / B)$ was US $\$ 1.50$, and IRR was $48.38 \%$. For Super ${ }^{\circledR}$ NPV was US\$50842.28, $(C / B)$ of US\$1.49 and IRR of $47.03 \%$ (Table 5). NPV was estimated for one production cycle per year (210-240 days). In tropical weather conditions, the environmental temperature does not affect growth. However, it is advisable to harvest before the end of December. 
Table 1. Muscle proximal composition of tropical gar fed with two commercial diets. Different letters in a row indicate significant differences $(P<0.05)$.

\begin{tabular}{lcrr}
\hline Nutrients & Initial & \multicolumn{1}{c}{ Silver Cup } & \multicolumn{1}{c}{ Super $^{\circledR}$} \\
\hline Proteins (\%) & $85.62 \pm 0.28^{\mathrm{a}}$ & $65.8 \pm 2.26^{\mathrm{c}}$ & $75.5 \pm 0.20^{\mathrm{b}}$ \\
Lipids (\%) & $5.49 \pm 0.04^{\mathrm{c}}$ & $24.7 \pm 1.76^{\mathrm{a}}$ & $16.6 \pm 0.48^{\mathrm{b}}$ \\
Humidity (\%) & $8.55 \pm 0.03^{\mathrm{a}}$ & $1.2 \pm 0.54^{\mathrm{b}}$ & $9.4 \pm 1.41^{\mathrm{a}}$ \\
Ashes (\%) & $4.65 \pm 0.07^{\mathrm{a}}$ & $3.4 \pm 0.12^{\mathrm{c}}$ & $4.0 \pm 0.07^{\mathrm{b}}$ \\
Fibers (\%) & $0.04 \pm 0.02^{\mathrm{b}}$ & $0.11 \pm 0.04^{\mathrm{a}}$ & $0.11 \pm 0.03^{\mathrm{a}}$ \\
Energy (Kcal g & \\
\hline
\end{tabular}

Table 2. Initial investment required to produce 3,600 tropical gars. ${ }^{a}$ Hidromecánica y Sistemas de Bombeo S. de R.L. de C.V., Villahermosa, Tabasco, México. ${ }^{b}$ Estimated budget made by a local construction company, Villahermosa, Tabasco, México. ${ }^{\mathrm{c} C o m i s i o ́ n ~ F e d e r a l ~ d e ~ E l e c t r i c i d a d ~(C F E), ~ M e ́ x i c o . ~}{ }^{\mathrm{d}}$ ARIGEM, Centro, Tabasco, México. ${ }^{\mathrm{e}}$ The Home Depot, Local Store in Villahermosa, Tabasco, México.

\begin{tabular}{lrcr}
\hline Input & $\begin{array}{c}\text { Unitary cost } \\
\text { (US\$) }\end{array}$ & $\begin{array}{c}\text { Quantity } \\
\text { (units) }\end{array}$ & $\begin{array}{c}\text { Total cost } \\
\text { (US\$) }\end{array}$ \\
\hline Water pump $^{\mathrm{a}}$ & 121.51 & 2 & 243.02 \\
Ground preparation $^{\mathrm{b}}$ & 369.98 & 1 & 369.98 \\
Power plant $^{\mathrm{c}}$ & $1,003.17$ & 1 & $1,003.17$ \\
Well construction $^{\mathrm{b}}$ & 475.69 & 1 & 475.69 \\
Geomembrane pond $^{\mathrm{d}}$ & 528.54 & 6 & $3,171.24$ \\
Pond materials $^{\mathrm{d}}$ & 281.43 & 6 & $1,688.57$ \\
Electrical installation $^{\mathrm{c}}$ & 179.70 & 1 & 179.70 \\
Water reservoir filters $^{\mathrm{e}}$ & 52.85 & 1 & 52.85 \\
Land/m $^{2}$ & 12.68 & 500 & $6,342.49$ \\
Total & & & $13,526.73$ \\
\hline
\end{tabular}

Table 3. Production cost calculated for producing 120 fish with two different commercial feed.

\begin{tabular}{lcr}
\hline \multirow{2}{*}{ Input } & \multicolumn{2}{c}{ Cost $($ US\$) } \\
\cline { 2 - 3 } & Silver Cup & \multicolumn{1}{c}{ Super } \\
\hline Fry & 158.56 & 158.56 \\
Feeding $\left(f_{c}\right)$ & 111.80 & 91.83 \\
Energy $\left(E_{c}\right)$ & 184.49 & 184.49 \\
Labor $\left(L_{c}\right)$ & 888.39 & 888.39 \\
Veterinarians $\left(V_{c}\right)$ & 47.57 & 47.57 \\
Total $\left(T_{c}\right)$ & $1,390.81$ & $1,370.84$ \\
\hline
\end{tabular}

\section{DISCUSSION}

Results indicated that fish fed with Super ${ }^{\circledR}$ diet obtained a less than average growth than those fed with Silver Cup $^{\circledR}$. Super ${ }^{\circledR}$ diet contained less protein (4\% less). In this sense, Carrillo (2011) did not find differences among weight and size in tropical gar fed with three commercial feeds (Tilapia 38\% CP; Tilapia 38\% + oil and trout feed), although was observed a high weight and length dispersion between diets.

Water quality parameters did not exceed the allowable limits (Márquez-Couturier et al., 2013); thus, they did not have an impact on growth. The experiment
Table 4. Costs and revenues estimated for producing 3,600 tropical gars per diet.

\begin{tabular}{lrr}
\hline \multirow{2}{*}{ Description } & \multicolumn{2}{c}{ Value (US\$) } \\
\cline { 2 - 3 } & Silver Cup & \multicolumn{1}{c}{ Super $^{\circledR}$} \\
\hline Total cost $(T c)$ & $6,852.97$ & $6,253.76$ \\
Sales income $(T v)$ & $13,571.53$ & $12,509.41$ \\
Profit $(U)$ & $6,718.56$ & $6,255.65$ \\
\hline
\end{tabular}

Table 5. Economic profitability for producing 3,600 tropical gars per diet. ${ }^{\mathrm{a}} \mathrm{Calculated}$ on a $10 \%$ annual minimum acceptable rate of return (MARR). NPV: Net Present Value, C/B: Cost/Benefit, IRR: Internal Return Rate.

\begin{tabular}{ccc}
\hline Description & Silver Cup $^{\circledR}$ & Super $^{\circledR}$ \\
\hline NPV & ${\text { US } \$ 55,332.63^{\mathrm{a}}}$ & ${\text { US } \$ 50,842.28^{\mathrm{a}}}$ \\
C/B & ${\text { US } \$ 1.50^{\mathrm{a}}}$ & US $\$ 1.49^{\mathrm{a}}$ \\
IRR & $48.38 \%$ & $47.03 \%$ \\
\hline
\end{tabular}

showed the survival of $98.87 \%$, which agrees with other carnivorous and omnivorous fish in growth experiments; rainbow trout Oncorhynchus mykiss 96.3\% (García-Macías et al., 2004) and channel catfish Ictalurus punctatus $97 \%$ (Yildirim et al., 2007). 
Average weight and size for each fish were suitable concerning market price (Márquez-Couturier et al., 2013) of US $\$ 4.23$ year average (with fluctuations to US\$5.29 in seasons of supply shortages), for fish between 400 to $550 \mathrm{~g}$ and 40 to $50 \mathrm{~cm}$ in size.

The chemical proximal analysis suggested that the nutritional quality of tropical gar fed with $\mathrm{Super}^{\circledR}$ is better than those fed with Silver Cup ${ }^{\circledR}$, because fish fed with Super ${ }^{\circledR}$ contained a higher amount of protein, and hence, could have a less viscerosomatic index and greater carcass meat yield, as happen in O. mykiss (Francesco et al., 2004; García-Macías et al., 2004). In the near future, better meat quality could result in an advantage for the market, as this could allow greater diversity in products (such as fillets and meat medallions), increasing the income potential. JesúsContreras (2016), found that Atractosteus tropicus fed with Super ${ }^{\circledR}$ had better sensory quality (taste, texture, color, etc.) than those fed with Silver $\mathrm{Cup}^{\circledR}$, and wild fish.

The production cost per fish was US $\$ 1.90$ for Silver $\mathrm{Cup}^{\circledR}$ and US\$1.74 for Super $^{\circledR}$, not taking into consideration the initial investment. These costs allow us to obtain almost double profits having a market value of US\$4.23, which may indicate that producing 3,600 fish is superior to the break-even point. Both methods are better than the one used by González et al. (2011), where they found that in order to reach the balance point is need it to produce 7,875 organisms of $500 \mathrm{~g}$ in average.

Profitability indicators of this study (Table 5), indicated that both treatments have economic viability because NPV in both cases was positive; C/B was greater than 1 , indicating that with each dollar invest the profit will be US\$0.49 for both cases. Both IRR is acceptable, which are greater than the MARR set in $10 \%$ yield, according to proposed by Barry \& Ellinger (2010), that the grow-out of tropical gar with both diets is a profitable business.

As the profitability is greater with Silver Cup ${ }^{\circledR}$, added to the differences found in individual growth during grow-out with Super ${ }^{\circledR}$ could suggest that an increment in protein availability in the diet might result in better growth as proved in O. mykiss (García-Macías et al., 2004), which also improve the profitability indicators with diet Super ${ }^{\circledR}$.

The NPV and C/B obtained in this study for both cases (Table 5) was superior to those reported by González et al. (2011) with Silver Cup ${ }^{\circledR}$, obtaining an NPV of US\$6333.25 and a C/B of US\$1.08. Our IRR for both diets is higher than those obtained by González et al. (2011) (25.6\%), which suggest that a monoculture with both diets, could be an activity with high potential for investment return. This same author suggests that a polyculture with species such as; Mayan cichlid (Cichlasoma urophthalmus) and tilapia (Oreochromis niloticus), could considerably increment the profitability indicators having an IRR of $145 \%$. Even if polyculture could amortize the investment in tropical gar production, this will increment the grow-out time considerably by decreasing the feed conversion ratio from 1.9 in monoculture to 0.9 in polyculture (Márquez-Couturier et al., 2013), suggesting a considerable increment in electric and labor costs.

Despite lower growth using Super ${ }^{\circledR}$ diet, the proximal analysis showed that the nutritional value based on higher protein and fewer lipids content was greater than using Silver Cup ${ }^{\circledR}$. This suggests a better product with higher carcass meat yield. More protein in muscle and less mesenteric fat suggest better market opportunities for A. tropicus, like fillets commercialization and gourmet dishes, thus giving support to the conclusion that Super $^{\circledR}$ represents a better way to grow out this species in the long term.

Additionally, IRR, C/B and NPV of tropical gar production indicated profitability using both diets. A better nutritional quality was observed using Super ${ }^{\circledR}$ diet, less feeding cost, as well as better market adaptability, so it is concluded that using Super ${ }^{\circledR}$ feed for grow-out tropical gar is a better alternative in a pilot commercial scale.

\section{ACKNOWLEDGMENTS}

To Consejo Nacional de Ciencia y Tecnología (CONACYT) for the student fellowship and Programa de Fortalecimiento de la Calidad Educativa (PFCE), SEP, 2019 for publishing funds.

\section{REFERENCES}

Association of Official Analytical Chemists (AOAC). 2000. Official methods of analysis. Association of Official Analytical Chemists, Arlington, Virginia.

Barry, P.J. \& Ellinger, P.N. 2010. Financial management in agriculture. Prentice Hall, New Jersey.

Carrillo, O.H.L. 2011. Evaluación del potencial acuícola de Atractosteus tropicus (Pejelagarto) para la diversificación de la piscicultura nacional. Informe final, Proyecto FODECYT 71-2007. Centro de Estudios del Mar y Acuicultura, Ciudad de Guatemala.

Diario Oficial de la Federación (DOF). 2017. Resolución del H. Consejo de Representantes de la Comisión Nacional de los Salarios Mínimos que fija los salarios mínimos general y profesionales vigentes a partir del 
$1^{\circ}$ de enero de 2018. DOF: 21/12/2017. http://dof.gob. $\mathrm{mx} /$ nota_detalle.php? codigo $=5508586 \&$ fecha $=21 / 12 /$ 2017. Reviewed: 2 September 2018.

Francesco, M., Parisi, G., Médale, F., Lupi, P., Kaushik, S.J. \& Poli, B.M. 2004. Effect of long-term feeding with a plant protein mixture based diet on growth and body/filler quality traits of large rainbow trout (Oncorhynchus mykiss). Aquaculture, 236: 413-429.

Frías-Quintana, C.A., Álvarez-González, C.A. \& MárquezCouturier, G. 2010. Design the microdiets for larvicultive alligator gar Atractosteus tropicus. Universidad y Ciencia, 26(2): 265-282.

Frías-Quintana, C.A., Domínguez-Lorenzo, J., ÁlvarezGonzález, C.A., Tovar-Ramírez, D. \& MartínezGarcía, R. 2016. Using cornstarch in microparticulate diets for larvicultured tropical gar (Atractosteus tropicus). Fish Physiology and Biochemistry, 42(2): 517-528.

Frías-Quintana, C.A., Márquez-Couturier, G., ÁlvarezGonzález, C.A., Tovar-Ramírez, D., Nolasco-Soria, H., Galaviz-Espinosa, M.A. \& Gisbert, E. 2015. Development of digestive tract and enzyme activities during the early ontogeny of the tropical gar Atractosteus tropicus. Fish Physiology and Biochemistry, 41(5): 1075-1091.

Frías-Quintana, C.A., Álvarez-González, C.A., TovarRamírez, D., Martínez-García, R., Camarillo-Coop, S., Peña, E. \& Galaviz, M.A. 2017. Use of potato starch in diets of tropical gar (Atractosteus tropicus, Gill 1863) larvae. Fishes, 2(3): 11 pp.

García-Macías, J.A., Núñez-González, F.A., ChacónPineda, O., Alaro-Rodríguez, R.H. \& EspinosaHernández, M.R. 2004. Calidad en canal y carne de trucha arcoíris Oncorhynchus mykiss Richardson, producida en el noroeste del estado de Chihuahua. Hidrobiológica, 14(1): 19-26.

González, E.J.M., Ramírez, O.A., Figueroa, E.H. \& Loera, J.M. 2011. Evaluación financiera de producción de pejelagarto (Atractosteus tropicus): caso cooperativa de producción pesquera acuícola "El Pejelagarto" S.C. de R.L. Quinta Época, 15(29): 704-718.

Guerrero-Zarate, R., Álvarez-González, C.A., OlveraNovoa, M.A., Perales-García, N., Frías-Quintana, C.A., Martínez-García, R. \& Contreras-Sánchez, W.J. 2013. Partial characterization of digestive proteases in tropical gar Atractosteus tropicus juveniles. Fish Physiology and Biochemistry, 40: 1021-1029.
Jesús-Contreras, R. 2016. Evaluación de alimentos balanceados para el cultivo intensivo de juveniles de pejelagarto (Atractosteus tropicus). Tesis de Maestría, División Académica de Ciencias Biológicas, Universidad Juárez Autónoma de Tabasco, Tabasco, 112 pp.

Kay, R.D., Edwards, W.M. \& Duffy, P.A. 2012. Farm management. McGraw-Hill, New York.

Márquez-Couturier, G. \& Vázquez-Navarrete, C.J. 2015. Estado del arte de la biología y cultivo de pejelagarto (Atractosteus tropicus). Agroproductividad, 8(3): 4451.

Márquez-Couturier, G., Vázquez-Navarrete, C.J., ContrerasSánchez, W. \& Álvarez-González, C.A. 2013. Acuicultura tropical sustentable: una estrategia para la producción y conservación del pejelagarto (Atractosteus tropicus) en Tabasco, México. Universidad Juárez Autónoma de Tabasco, Tabasco.

Márquez-Couturier, G., Álvarez-González, C.A., ContrerasSánchez, W., Hernández-Vidal, U., Hernández-Franyutti, A.A., Mendoza-Alfaro, R., Aguilera-González, C., García-Galano, T., Civera-Cerecedo, R. \& GoytortuaBores, E. 2006. Avances en la alimentación y nutrición del pejelagarto Atractosteus tropicus. VIII Simposium Internacional de Nutrición Acuícola, Universidad Autónoma de Nuevo León, Monterrey, pp. 446-523.

Miller, R.R., Minckley, W.L., Norris, S.M. \& Gach, M.H. 2009. Peces dulceacuícolas de México. Comisión Nacional para el Conocimiento y Uso de la Biodiversidad, Sociedad Ictiológica Mexicana, A.C., El Colegio de la Frontera Sur, y Consejo de los Peces del Desierto, Ciudad de México.

Poot-López, G., Hernández, J.M. \& Gasca-Leyva, E. 2014. Analysis of ration size in Nile tilapia production: economics and environmental implications. Aquaculture, 420-421: 198-205.

Vázquez-Navarrete, C.J. \& Márquez-Couturier, G. 2010. Characterization of the supply network of the tropical gar (Atractosteus tropicus) in Tabasco, Mexico. International Network for Lepisosteid Research, Nicholls State University, Louisiana.

Yildirim, A.M., Richard, S., Lim, C. \& Phillip, H.K. 2007. Growth performance and proximate and fatty acid compositions of channel catfish, Ictalurus punctatus, fed for different duration with a commercial diet supplemented with various levels of menhaden fish oil. Journal of the World Aquaculture Society, 38(4): 461-474. 